\title{
O Intercâmbio Comercial Brasil-China: A Questão das Vantagens Comparativas
}

\section{The International Trade between Brazil and China: A Comparative Advantage Approach}

\author{
Paulo Ricardo Feistel* \\ Álvaro Barrantes Hidalgo**
}

\begin{abstract}
Resumo: O objetivo deste trabalho é conhecer melhor as características do fluxo comercial entre Brasil e China. São analisados diversos aspectos das relações comerciais entre os dois países: mudança na estrutura, comércio intraindústria, intensidade tecnológica e aproveitamento de vantagens comparativas. $\mathrm{O}$ assunto é relevante tendo em vista a crescente importância da economia chinesa no cenário internacional e o crescimento do fluxo comercial verificado entre os dois países nas duas últimas décadas. Foram encontrados baixos índices de comércio intraindústria entre os dois países e baixa (alta) intensidade tecnológica nas exportações (importações) brasileiras. Os dados parecem mostrar uma tendência de especialização do comércio exterior brasileiro com a China. Com base na técnica de insumo produto, e considerando o modelo das proporções de fatores com três fatores de produção, é feita uma análise das intensidades fatoriais no comércio, a mesma mostra as exportações brasileiras como sendo mais intensivas em recursos naturais e as importações mais intensivas em capital, sendo que os bens intensivos em trabalho apresentaram baixa representatividade comercial entre os dois países. Assim os resultados parecem mostrar-se condizentes com os preceitos das vantagens comparativas caso, seja aceito o Brasil como sendo relativamente abundante em recursos naturais e relativamente escasso em capital, quando comparado com a China.
\end{abstract}

Palavras-chave: Abertura comercial. Comércio Brasil-China. Vantagens comparativas.

Abstract: The aim of this paper is to better understand the commercial flow's characteristics between Brazil and China. Various aspects of the commercial rela-

* $\quad$ Professor do Departamento de Economia da Universidade Federal de Santa Maria (UFSM).

* * Professor do Departamento de Economia e do Curso de Pós-Graduação em Economia da Universidade Federal de Pernambuco (UFPE) e pesquisador do CNPq.

Os autores agradecem comentários recebidos de parecerista anônimo desta revista. Erros e omissões remanescentes são, naturalmente, de inteira responsabilidade dos autores. 
tions between these two countries are analyzed: structure changes, intra-industry trade, technological intensity and exploitation of comparatives advantages. This issue is relevant in view of the important growing of the Chinese economy in the international scene and the growth of the commercial flow observed between these countries in the last two decades. Low levels of intra-industry trade between these two countries were found and low (high) technological intensity in the Brazilian exportations (importations). The data seems to show a trend to specialization of the external Brazilian trade with China. Based on the input-output technique and considering the proportional factors with three production factors model, a factorial intensity analysis in the trade is made. This one, shows Brazilians exportations as more intensives in natural resources and the importations more intensives in capital, and the labor intensive goods had low commercial representation between the two countries. Thus, the results seem to agree with the precepts of the comparatives advantages in case of Brazil be accepted as relatively abundant in natural resources and relatively scarce in capital, when it's compared with China.

Keywords: Trade Liberalization. Brazil-China trade. Comparative Advantages. JEL Classification: F15.

\section{1 lntrodução}

Nas duas últimas décadas o sistema de comércio internacional sofreu mudanças muito importantes. O processo de liberalização comercial e a formação de blocos regionais de comércio foram aprofundados. No entanto, a eliminação das barreiras tarifárias trouxe aos países o receio de que a globalização destruísse seus setores produtivos, que então passaram a adotar outras formas de proteção não tarifárias. Surgia o "novo protecionismo", que aliado à complexidade de negociar a liberalização do comércio de maneira multilateral, serviu de incentivo para a formação de blocos regionais de comércio entre grupos reduzidos de países.

O Brasil, na década de 90, iniciou uma política de liberalização do comércio externo a fim de tornar a economia mais eficiente e atender às expectativas de inserção nas economias globalizadas. O processo foi realizado juntamente com a promoção da estabilidade da economia brasileira, principalmente o controle da inflação, privatizações e o surgimento e inserção do Brasil no Mercosul. A nova conjuntura da economia mundial e a política macroeconômica interna alteraram as relações de comércio do Brasil com seus parceiros comercias.

Na última década as exportações brasileiras apresentaram um crescimento significativo quando comparado com a década anterior. Durante a década dos noventa as exportações do Brasil cresceram a uma taxa média de 5,7 \% ao ano, passando para $17,3 \%$ ao ano durante o período 2000 a 2008. Paralelamente a 
expansão do comércio houve, e está acontecendo, uma mudança não apenas na estrutura do comércio brasileiro, mas também na direção dos fluxos comerciais, a exemplo do crescimento do comércio Brasil-China.

A China tem tido um papel preponderante na expansão recente do comércio mundial. Comparando o desempenho comercial do Brasil e da China temos que as exportações brasileiras mais que duplicaram nos últimos dez anos, mas o desempenho brasileiro ficou aquém do chinês no mesmo período. Segundo dados elaborados pela Associação de Comércio Exterior do Brasil (AEB), as exportações brasileiras cresceram 149,6\% entre 2000 e 2009. No mesmo período, as vendas externas da China avançaram em $288,9 \%$. Num prazo mais longo, a diferença é ainda maior. Quanto à estrutura das exportações também há diferenças marcantes. No caso brasileiro temos que os manufaturados representam $35 \%$ das vendas externas (excluindo commodities industrializadas, como açúcar refinado), enquanto que essa taxa salta para $90 \%$, no caso da China.

No que se refere ao comércio bilateral Brasil-China temos que no ano 2000 o comércio brasileiro com a China representava por volta de $2 \%$ do total, ao passo que no ano de 2009 a China passou a ser o principal parceiro comercial do Brasil, sendo direcionadas para esse país 13,3 \% das exportações brasileiras. Por outro lado, as importações do Brasil da China representaram 12,4\% das importações totais naquele ano. Dessa forma a China passou a ser o mais importante parceiro comercial brasileiro em 2009, posição esta, antes desempenhada pelos Estados Unidos. Quanto à balança comercial entre os dois países, esta tende a ser deficitária para o Brasil, principalmente em períodos de maior crescimento econômico interno.

O estreitamento das relações comerciais do Brasil com a China aponta para um crescimento vigoroso, juntando-se ao clube dos principais parceiros comercias do Brasil para as próximas décadas.

Paralelamente ao crescimento do comércio brasileiro houve e está acontecendo uma mudança na estrutura do comércio. As exportações brasileiras mostram um crescimento maior dos primários quando comparado com os manufaturados, sendo este fato, visto com preocupação por parte de alguns críticos.

A estrutura do comércio exterior brasileiro reflete o desempenho de seus setores produtivos de commodities e manufaturados, tornando a economia doméstica mais competitiva no cenário mundial fomentando e diversificando a pauta de exportações e importações. Segundo dados do Ministério do Desenvolvimento, Indústria e Comércio (MDIC), nos últimos cinco anos, a média das vendas brasileiras para o resto do mundo - inclusive a China - representaram $46,8 \%$ de produtos básicos, 13,9\% de produtos semimanufaturados e 39,3\% de produtos manufaturados. Por outro lado as importações brasileiras estiveram, em média, concentradas 
em manufaturados com $56,5 \%$ de participação, os produtos semimanufaturados tiveram uma participação de 25,1 \% e os produtos básicos 18,4\% de participação.

O tema da ascensão da China e as relações comerciais Brasil-China vêm ganhando recentemente o interesse por parte de estudiosos. Cunha et al. (2011) analisam a ascensão da China e seus impactos sobre a economia brasileira. Por outro lado, Devlin, Estevadeordal e Rodríguez (2006) discutem as oportunidades e os desafios que a ascensão da China oferece para o crescimento da América Latina. Diversos trabalhos da CEPAL, por exemplo, CEPAL (2010), também, analisam os efeitos da China sobre América Latina. Quanto ao comércio Brasil-China, boa parte dos trabalhos se concentra no estudo dos efeitos da ascensão da China sobre as exportações brasileiras de manufaturados. Assim, por exemplo, Lélis, Cunha e Lima (2010) mostram que as exportações chinesas estão avançando sobre mercados previamente ocupados pelo Brasil na América Latina. Silva (2011) também analisa a concorrência chinesa, avaliando os riscos da entrada de produtos chineses para as exportações brasileiras em terceiros mercados tais como Nafta, Mercosul e países da África. Dentro da mesma linha de análise, Hiratuka e Sarti (2009) avaliam a ameaça das exportações chinesas às exportações de manufaturados do Brasil no Mercosul, Aladi e Nafta, para fazer a análise os autores utilizam indicadores de market-share, similaridade das pautas e grau de diversificação das exportações dos dois países nesses mercados. Machado e Ferraz (2006) discutem o padrão de comércio brasileiro com a China e os riscos para as exportações brasileiras da concorrência chinesa. Finalmente, Jorge e Kume (2009) estimam índices de similaridade, qualidade e variabilidade das exportações do Brasil e da China no mercado norte-americano no período 2000-2008.

Tendo em vista o crescimento do comércio Brasil-China acima relatado e a crescente importância da China no cenário internacional, o objetivo principal deste trabalho é conhecer melhor a natureza do comércio entre os dois países, analisar a mudança na estrutura do comércio e investigar o aproveitamento ou não das vantagens comparativas no comércio entre os dois países, assunto este último pouco estudado nas relações comerciais entre os dois países. O estudo dessas questões é relevante não apenas para o entendimento das mudanças recentes no comércio exterior brasileiro, mas também para a formulação das políticas de comércio exterior.

A fim de atingir os resultados, o artigo está dividido em cinco seções. $\mathrm{Na}$ seção dois apresentaremos uma análise a fim de conhecer melhor o crescimento e as mudanças acontecidas na estrutura do comércio exterior brasileiro com a China durante o período pós-abertura comercial. Na seção três, apresentaremos o método que será utilizado para conhecer melhor o uso dos fatores produtivos no comércio exterior entre os dois países. Na seção quatro, apresentaremos a análise 
dos resultados que foram obtidos, e finalmente na seção cinco apresentaremos as conclusões do trabalho.

\section{Crescimento e Mudança na Estrutura do Comércio Exterior Brasil-China}

A fim de conhecer melhor o crescimento e as mudanças acontecidas na estrutura do comércio exterior brasileiro com a China no período recente, neste trabalho foram agrupados os produtos que participam do comércio entre os dois países em 14 grupos de produtos ${ }^{1}$. Assim, na Tabela 1 é apresentada a estrutura das exportações brasileiras para o período de 1989 a 2009 segundo essa classificação, na última coluna dessa Tabela é mostrada a taxa de crescimento anual das exportações em cada grupo de produtos durante o período.

Observa-se nessa Tabela, que o grupo de produtos Alimentos e Bebidas, que sabidamente tem forte conteúdo de recursos naturais, é o grupo que historicamente apresenta a maior representatividade dentro das exportações do Brasil para a China. Embora no início do período analisado não se mantenha um padrão definido, a partir do ano 1995 houve uma participação significativa deste grupo nas exportações para este país. Assim, em 1989 o grupo Alimentos e Bebidas representavam 21,31\% do total exportado para China, reduzindo para 13,35\% em 1992, elevando significativamente a participação em 1995 para 59,38\% e voltando a cair para o nível de representatividade de 31,32\% em 1997. Após o ano de 1997 houve crescimento continuo deste grupo chegando a representar em 2008 40,58\% das exportações brasileiras. No entanto, no ano de 2009, o grupo Alimentos e Bebidas, sofreram o impacto negativo da crise financeira internacional, que se refletiu no comércio internacional com redução de participação para 36,42\%, certamente a crise financeira foi determinante para este desempenho da demanda chinesa por bens do grupo Alimentos e Bebidas originárias do Brasil.

Outro grupo de produtos primários que tem importante destaque na pauta das exportações brasileiras para a China é o grupo Minerais (minérios, combustíveis, etc.). Esse grupo, que também tem forte presença de conteúdo de recursos naturais, e com baixo valor agregado, apresentou aumento na representatividade durante o período analisado com um crescimento médio anual de 30,91\%, superior inclusive que o grupo de Alimentos e Bebidas que foi da ordem de 22,17\%. Observa-se, também, na Tabela 1 que o grupo dos Minerais, passou a ser o segundo maior grupo em termos de representatividade nas exportações brasileiras para a China. A participação dos Minerais que era de apenas 6,29\% em 1989, se intensificou a partir de 1999 quando atingiu 36,86\%, chegando a representar 42,8\% em 2009 do valor total exportado para este país.

$\overline{1}$ O critério de agrupação dos produtos segue de perto aquele sugerido por Thorstensen et al. (1994), critério este muito utilizado em diversos trabalhos sobre comércio exterior. 
Dentre os bens primários, o grupo de Minerais Não-Metálicos apresentou uma redução na participação relativa no período analisado, passando de $44,65 \%$ em 1989 para atingir vinte anos depois a representatividade de apenas 5,30\% em 2009.

Com relação aos grupos de produtos manufaturados, observa-se, na Tabela 1, a evolução do grupo de produtos Máquinas e Equipamentos, tradicionalmente intensivos em capital, e que tem alto valor agregado. Esse grupo de produtos, que apresentou uma participação modesta nas exportações com apenas 1,43\% de representatividade em 1989, saltou para o patamar de 11,91\% em 1997, voltando ao patamar do inicio do período analisado ao ser responsável por apenas 1,31\% das exportações para a China em 2009. O grupo Material de Transporte também, altamente intensivo em capital, mostra comportamento semelhante ao grupo Máquinas e Equipamentos, com uma participação relativamente modesta de 1,74\% em 1989 do total exportado para China, em 1997 atinge uma participação eventual de $10,60 \%$ e recuando para o patamar de 1,81\% em 2009. Esporadicamente, outros grupos de produtos manufaturados, apesar de não manterem um padrão definido, tiveram saltos significativos na participação relativa das exportações brasileiras para a China após a abertura comercial, como é o caso do grupo de Metais Comuns (aço, ferro, alumínio, etc.), que representava 7,74\% das exportações em 1989, aumentando para 27,66\% em 1992, caindo para apenas 0,75\% em 1995 e após altos e baixos, atingindo o valor participativo de 1,89\% em 2009.

Os demais grupos de produtos manufaturados tiveram, ao longo do período analisado, participações relativamente baixas e não padronizadas nas exportações brasileiras, assim: o grupo Produtos Químicos teve participação média no período analisado de 2,51\%; o setor de Plásticos e Borrachas, que obteve participação média no período de 2,56\%, reduziu sua participação de 8,39\% em 1989 para apenas 1,89\% em 2009; Madeira e Mobiliário manteve a participação média de 1,13\%; Papel e Celulose 4,08\% e Ótica e Instrumentos 0,21\% de participação média nas exportações para a China. 


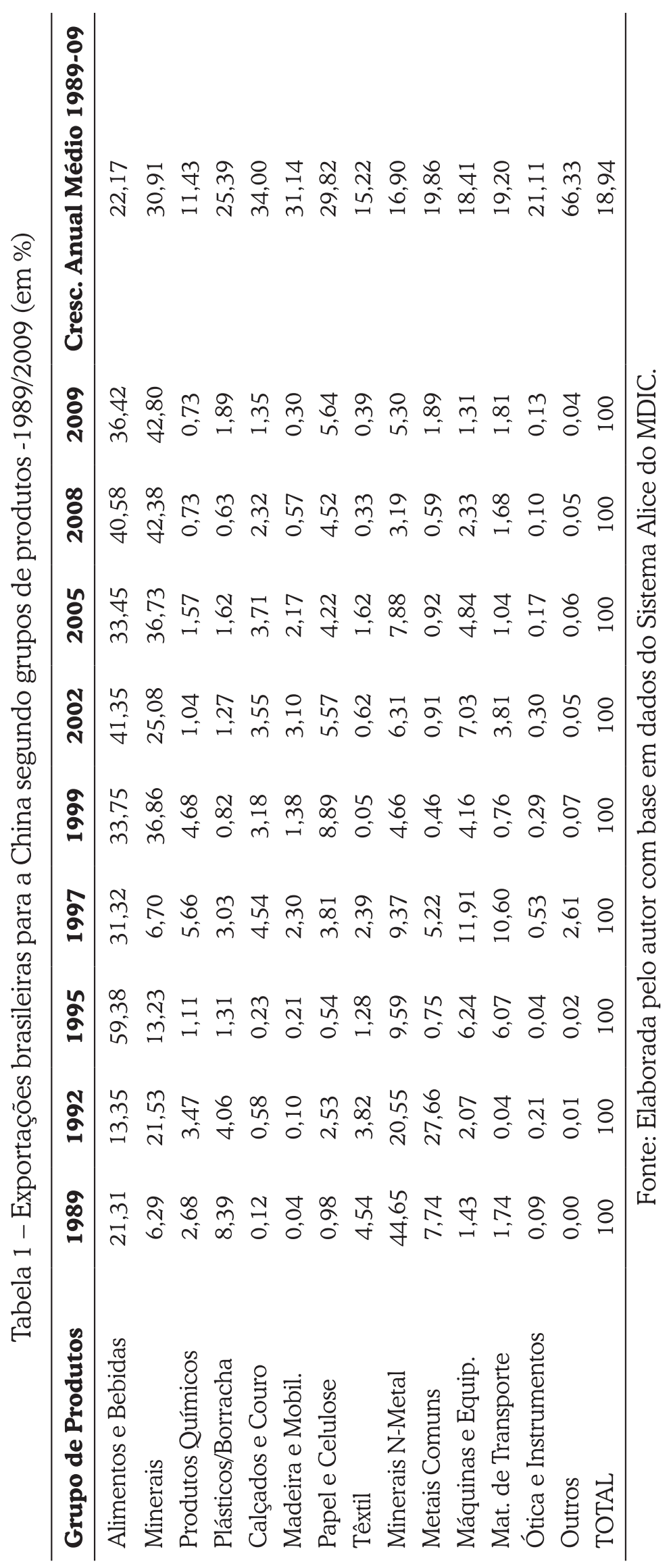

FEISTEL, P. R.; HIDALGO, A. B. O intercâmbio comercial Brasil-China: a questão... 
Por outro lado, os grupos de produtos de Calçados e Couros e Têxtil, tradicionalmente intensivos em trabalho, foram grupos de manufaturados que tiveram baixa participação relativa no período analisado. O grupo de Calçados e Couro que representavam $0,12 \%$ das exportações em 1989, após um pequeno aumento para 4,54\% em 1997, provocado provavelmente pelo deslocamento das indústrias do setor para a região Nordeste, região abundante em trabalho, teve uma redução continua na participação relativa, chegando em 2009 a representar apenas 1,35\% das exportações. Da mesma forma no grupo Têxtil, observa-se, na Tabela 1, uma queda ainda mais acentuada na participação das exportações, passando de 4,54\% em 1989 para apenas 0,39\% em 2009, restrições comerciais ao setor podem explicar esse baixo desempenho do setor.

Em resumo, durante o período após a abertura comercial os dois grupos de produtos primários: Alimentos e Bebidas, e Minerais tiveram altas taxas de crescimento nas exportações, fazendo com que a participação desses dois grupos de produtos primários juntos passasse de $27,6 \%$ em 1989 para quase $80 \%$ das exportações brasileiras para a China no final do período considerado. Os produtos manufaturados por sua vez, tiveram uma queda significativa na participação relativa e nenhuns dos grupos de produtos intensivos em trabalho considerados tiveram crescimento consistente de participação relativa ao longo do período analisado. As exportações de manufaturados para a China que em 1989 representavam $72,4 \%$ passaram a representar apenas $20,7 \%$ do total em 2009 . Evidencia-se, portanto, uma primarização nas exportações brasileiras para a China o período recente.

Analisando agora o comércio com a China pelo lado das importações, na Tabela 2, a seguir, é apresentada a estrutura das importações brasileiras da China segundo os diversos grupos de produtos considerados, na última coluna da Tabela é mostrada a taxa de crescimento anual das importações de cada grupo de produtos durante no período.

Observa-se que as importações brasileiras da China apresentaram um crescimento médio anual da ordem de $27,26 \%$ durante o período de 1989 a 2009, superior à média anual de 18,94\% de crescimento das exportações totais do Brasil verificado no mesmo período. Com relação à participação relativa dos grupos de produtos importados pelo Brasil cabem os seguintes comentários. Diferente das exportações, os dados mostram uma redução significativa na participação relativa das importações dos grupos de produtos primários de Alimentos e Bebidas, e de Minerais. Esses dois grupos representavam, respectivamente, 18,12\% e $51,42 \%$ do total importado pelo Brasil da China em 1989, reduzindo a sua participação relativa para apenas $1,46 \%$ e 0,80\% em 2009, respectivamente. Ou seja, a participação desses dois grupos de produtos primários caiu de 69,54\% em 1989 para o valor representativo mínimo de $2,26 \%$ em 2009 . Por outro lado, os produtos manufatura- 
dos tiveram um crescimento significativo de participação relativa nas importações após a abertura comercial, conforme será visto a seguir.

$\mathrm{Na}$ Tabela 2, observa-se o comportamento das importações brasileiras de manufaturados da China ao longo do período 1989/2009. Estas se concentraram nos grupos de: Produtos Químicos, Têxtil, Máquinas e Equipamentos, e Ótica e Instrumentos, que representavam juntamente 23,6\% do total importado em 1989 , a maioria desses grupos são produtos que podem ser considerados intensivos em capital. Contudo, a relação importação primários e manufaturados Brasil-China, se inverteu ao longo do período e em 2009 a participação desses quatro grupos de produtos passou a ser de $77,1 \%$ do total. Nestes grupos, observa-se o crescimento significativo das importações de Máquinas e Equipamentos, que em 1989 representavam apenas 7,35\%, passando a representar no ano de 2009 53,39\% do total importado da China. O grupo Produtos Químicos, que no inicio do período analisado, representava 14,42\% das importações, aumentou sua participação em 1992 para 26,56\% e nos períodos subsequentes após mostrar altos e baixos, declina sua representatividade para 9,98\% em 2009, desempenho inferior ao percentual verificado no ano de 1989. Já os grupos de Material de Transporte e Plásticos e Borrachas, tiveram um pequeno, mas continuo crescimento representativo de 0,10\% e 0,19\% em 1989, para 2,65\% e 3,05\% em 2009, respectivamente, do total importado pelo Brasil da China.

Com relação aos grupos de produtos considerados tradicionais na pauta de comércio exterior brasileiro e reconhecidamente na literatura econômica como sendo intensivos em trabalho temos os grupos de: Calçados e Couros, Madeira e Mobiliário, e Têxtil. Verifica-se que esses grupos tiveram recuo ou se mantiveram no mesmo nível de importância relativa nas importações brasileiras. No caso do grupo de Calçados e Couros, houve uma participação relativa média das importações de em torno de 4,55\%, no período analisado. O grupo Madeira e Mobiliário manteve uma representatividade média de importações de 0,15\% no período. Ainda, na Tabela 2, observa-se que o grupo de Têxtil, teve um crescimento das importações de $1,61 \%$ para $15,32 \%$ no ano de 1995 e posteriormente um declínio na representatividade para $8,60 \%$ em 2009. No desempenho deste grupo é possível verificar a agressividade comercial da economia chinesa, ao aumentar suas exportações para o Brasil, em um setor considerado intensivo em trabalho e no qual a economia brasileira é reconhecidamente abundante em relação ao resto do mundo. 


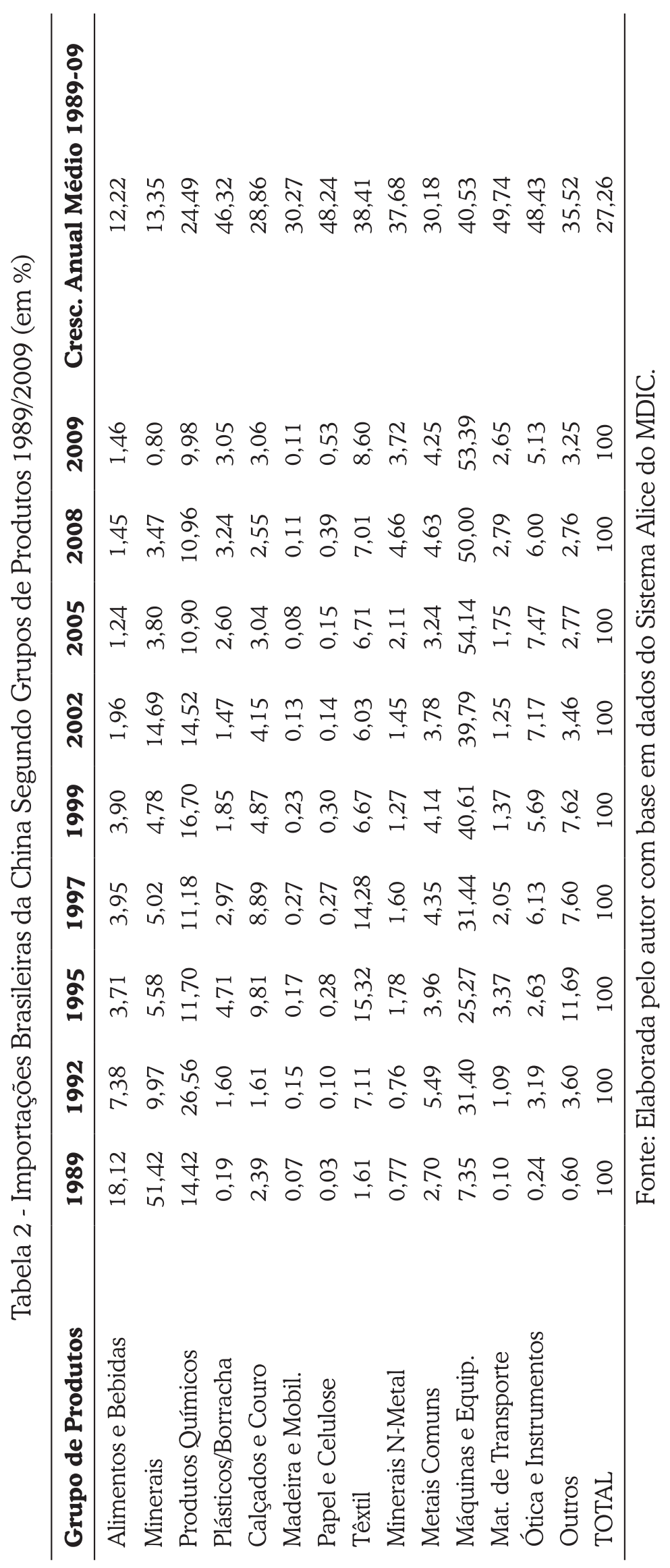


Nos demais grupos, merecem destaque o grupo de Metais Comuns. Esse grupo mostrou ao longo do período um crescimento de participação relativa das importações brasileiras da China, passando a representar 2,70\% em 1989 e 5,49\% em 1992, sofrendo redução na sua participação para 3,24\% em 2005 e recuperando a sua participação para 4,25\% em 2009. (Ver Tabela 2).

Por fim, temos na Tabela 2, os grupos restantes que não apresentaram variações significativas na participação relativa das importações brasileiras da China para o período analisado. O grupo de Minerais Não-Metálicos teve uma representatividade média de 1,79\%, o grupo de Papel e Celulose participou com média de $0,22 \%$ das importações brasileiras e, finalmente, o grupo de Ótica e Instrumentos, que aumentou a participação relativa atingindo média de 4,78\% do total importado pelo Brasil, no período de 1989 a 2009.

Em resumo, diferente das exportações, do lado das importações observase uma redução significativa na participação relativa das importações dos grupos de produtos primários, e um correspondente incremento na participação relativa dos manufaturados, principalmente daqueles mais intensivos em capital, como é o caso de máquinas e equipamentos que em 2009 representavam mais de 50\% do total importado pelo Brasil da China.

Outro indicador utilizado neste trabalho a fim de caracterizar o comércio exterior do Brasil com a China é o índice de comércio intraindústria (CII), trata-se de um índice que permite saber se o comércio realizado é de bens classificados dentro de um mesmo setor (comércio intraindústria), ou de bens classificados em setores diferentes (comércio interindustrial). O índice de CII foi desenvolvido por Grubel e Lloyd (1975). Esse índice pode ser calculado em nível de produto ou indústria, e também em nível agregado para toda a economia.

O indicador de comércio intraindústria agregado (CII), cunhado por Grubel e Lloyd (1975), e utilizado neste trabalho, é calculado com base na seguinte fórmula:

$$
C I I=1-\frac{\sum_{i}\left|X_{i}-M_{i}\right|}{\sum_{i}\left(X_{i}+M_{i}\right)}
$$

Onde $X_{\mathrm{i}}$ representa as exportações do produto i e $M_{i}$ representa as importações do mesmo produto ${ }^{2}$.

No Gráfico 1, são apresentados os índices de comércio intraindústria encontrados para o comércio Brasil-China, a nível agregado, dados referentes ao perí-

2 O valor numérico calculado desse índice encontra-se no intervalo entre zero e a unidade. Quando o índice CII iguala-se a 0, deparamo-nos com um comércio do tipo interindustrial, ou, em outras palavras, o comércio é do tipo à la Heckscher-Ohlin. Por outro lado, se o índice CII calculado é igual a 1, então todo o comércio é do tipo intraindústria.Ver detalhes sobre os determinantes do comércio intraindústria em Grubel e Lloyd (1975). 
odo 1989-2009. As observações utilizadas para o cálculo do índice CII foram em nível de capítulo da Nomenclatura Comum do Mercosul. Tendo em vista que o índice CII é sensível ao nível de agregação das observações (quanto mais agregadas as observações maior é o índice calculado), pode-se esperar que exista uma superestimação do índice de CII obtido.

Analisando o comportamento dos resultados obtidos, Gráfico 1, observa-se que não há um padrão definido do índice de comércio intraindústria do Brasil com relação à economia chinesa. Conforme pode ser visto no Gráfico, o padrão de comércio Brasil-China que inicialmente predomina no período é o comércio interindustrial, pois o índice de CII se apresenta muito baixo: 0,158 em $1989 \mathrm{e}$ 0,467 em 1990. 


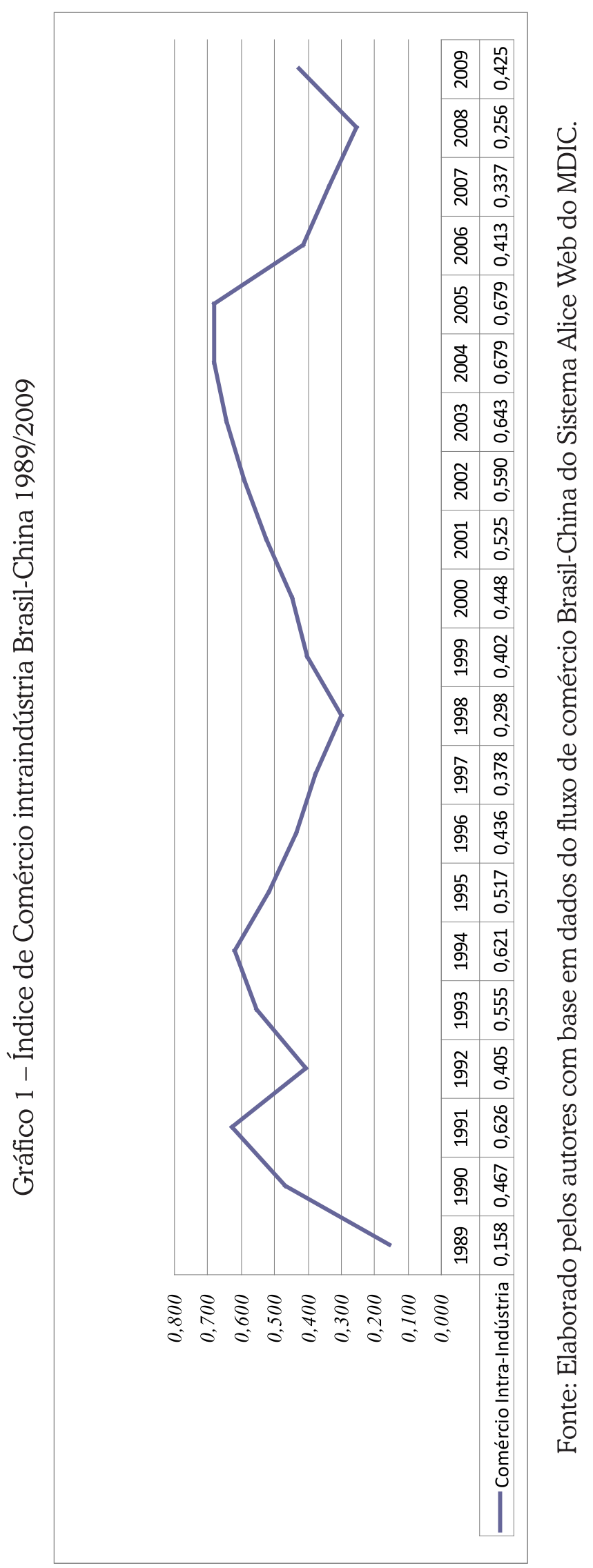

FEISTEL, P. R.; HIDALGO, A. B. O intercâmbio comercial Brasil-China: a questão... 
Somente nos anos de 1991, 1994 e no período de 2003 a 2005, os índices de CII parecem ser elevados. Entretanto os índices de comércio intraindústria encontrados para o comércio Brasil-China se situam abaixo dos níveis encontrados para o comércio entre o Brasil e o Resto do Mundo e para parceiros comerciais tradicionais como a Argentina e os demais países do Mercosul3 ${ }^{3}$. No caso do comércio Brasil-China, o predomínio do comércio parece ser interindustrial, esta caracterização do comércio é esperada por se tratar de um comércio que cresceu muito recentemente e está baseado na exportação de Alimentos e Bebidas, e Minerais, e em importações baseadas em manufaturados tais como Máquinas e Equipamentos, Produtos Químicos e Têxteis, como visto anteriormente 4 .

Outra perspectiva do comércio Brasil-China pode ser obtida analisando o comércio sob a ótica da intensidade tecnológica. No Gráfico 2 a seguir, são apresentados dados da CEPAL relativos ao comércio Brasil-China considerando a intensidade tecnológica. A análise da intensidade tecnológica considera cinco categorias de produtos: produtos primários, produtos manufaturados baseados em recursos naturais, manufaturados de baixa tecnologia, manufaturados de média tecnologia e manufaturados de alta tecnologia, dados relativos a 2009. A natureza do comércio interindustrial entre o Brasil e a China parece ser evidente, segundo o Gráfico 2 em 2009 por volta de $67 \%$ das importações brasileiras da China consistiam de produtos de média ou alta intensidade tecnológica, ao passo que as exportações brasileiras de manufaturados de média e alta intensidade tecnológica para esse país representavam apenas 10,2\%. Conforme mostrado no Gráfico o grosso da exportação brasileira para a China consistia naquele ano de produtos primários. Apenas o comércio de manufaturados baseado em recursos naturais parece estar perto do equilíbrio com $11 \%$ de participação tanto nas exportações quanto nas importações 5 .

3 Vasconcelos (2000), por exemplo, encontrou para o período 1995-1998, índices de CII no comércio Brasil- Argentina acima de 0,50.

4 Cunha et al. (2011) também encontraram baixos níveis de comércio intraindústria para o comércio Brasil-China, dados referentes ao período 1999-2008. Os autores concluem que o comércio bilateral Brasil-China tem um padrão interindustrial.

5 Dentro dessa lógica, as presenças de crescentes investimentos chineses no Brasil estão concentradas em projetos de media intensidade tecnológica no setor de matérias primas. 


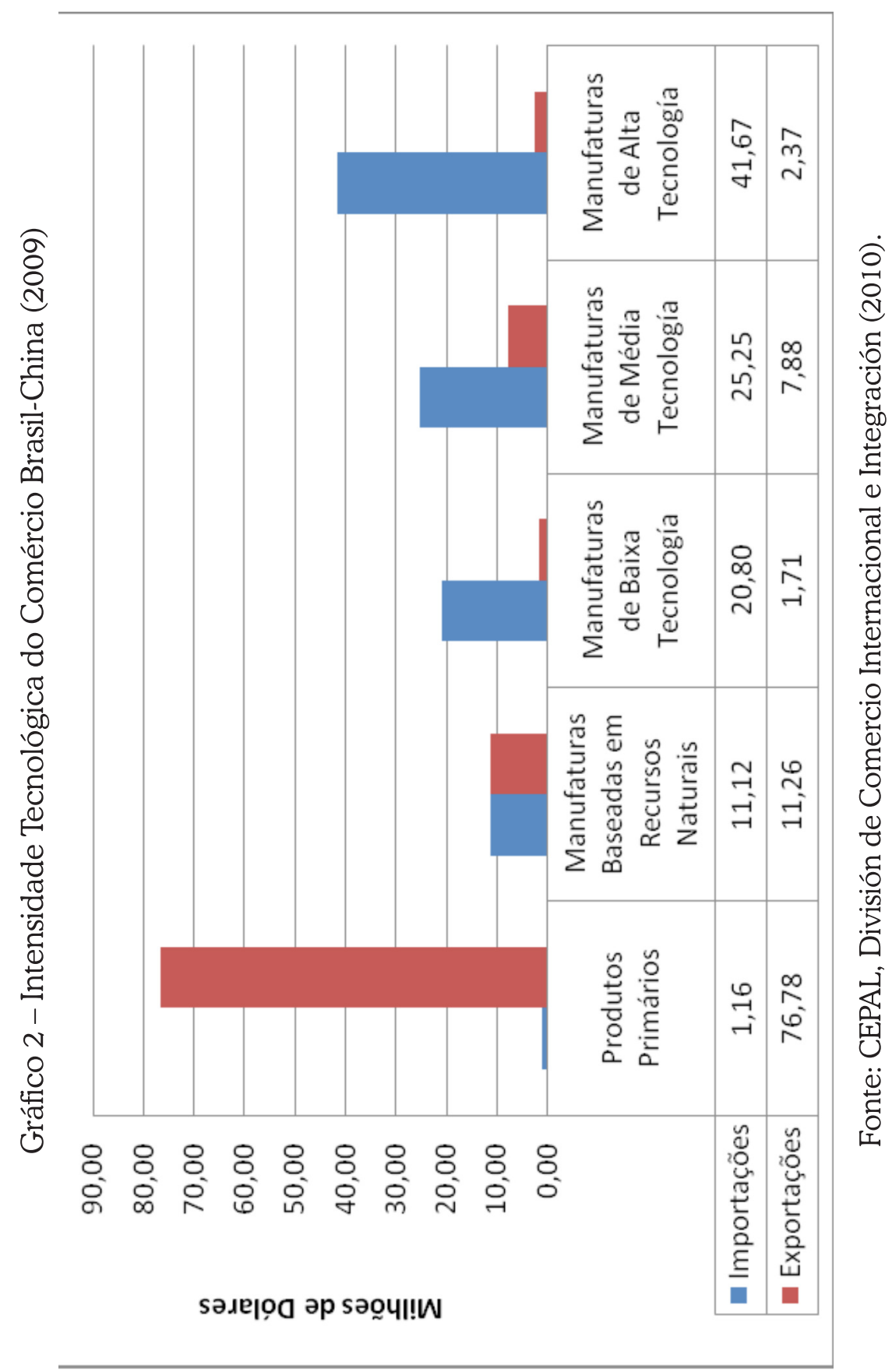

FEISTEL, P. R.; HIDALGO, A. B. O intercâmbio comercial Brasil-China: a questão... 
Os dados apresentados nas Tabelas 1 e 2, a análise do comércio intraindústria mostrada no Gráfico 1, e a intensidade tecnológica do comércio apresentada no Gráfico 2, parecem mostrar uma tendência de especialização do comércio exterior brasileiro com a China segundo os princípios das vantagens comparativas estáticas, principalmente durante o período recente. A economia brasileira é reconhecidamente bem dotada de recursos naturais (terra e minerais abundantes) e menos bem dotada de trabalho e capital, em relação à China. Nas seções a seguir realizar-se-á uma análise mais aprofundada sobre o uso de recursos produtivos no comércio exterior Brasil-China, a fim de conhecer melhor a tendência de especialização no comércio entre os dois países segundo as vantagens comparativas sob a ótica das intensidades fatoriais ${ }^{6}$.

\section{Método Utilizado para o Cálculo do Uso dos Fatores Produtivos no Comércio Brasil-China ${ }^{7}$}

A teoria padrão do comércio internacional baseada nas intensidades de fatores admite a existência de apenas dois produtos e dois fatores de produção. Para os objetivos deste trabalho, admitir-se-á a existência de três tipos de produtos ${ }^{8}$ : produtos intensivos em recursos naturais, produtos intensivos em trabalho e produtos intensivos em capital ${ }^{9}$.

Existem duas maneiras para se mensurar as intensidades fatoriais na economia. Primeiro, poder-se-ia mensurar o volume físico dos insumos de capital, trabalho e recursos naturais necessários para produzir um dado conjunto de bens. Uma segunda forma de mensuração das intensidades de fatores consiste na estimação da contribuição dos fatores de produção na formação do produto em cada setor da economia. Conceitualmente, a primeira dessas medidas é a mais recomendável

6 A teoria do comércio baseada nas intensidades de fatores é também conhecida como teoria neoclássica do comércio internacional ou de Heckscher-Ohlin. Existe na literatura sobre comércio outra versão clássica da teoria das vantagens comparativas baseada na produtividade do trabalho que não será analisada neste artigo. A versão clássica, conhecida também como teoria ricardiana do comércio internacional, defende que um país exportará (importará) produtos onde tiver maior (menor) produtividade o trabalho.

7 O método utilizado no cálculo do uso dos fatores de produção no comércio exterior está baseado em Hidalgo (1985) e Feistel (2006). Ver também Feistel e Hidalgo (2009).

8 A análise da teoria das proporções de fatores pode ser estendida ao caso onde existem três fatores de produção, desde que seja feita a hipótese de que existem três ou mais bens na economia, ver Kemp (1969). Samuelson (1954) discute aspectos da teoria das proporções de fatores quando existem " $m$ " fatores e " $n$ " bens em um modelo de equilíbrio geral.

9 Apesar de relevante, a inclusão na análise de um terceiro fator de produção, recursos naturais, envolve alguns problemas, tanto de natureza teórica quanto empírica. Existe a possibilidade que recursos naturais e capital, por exemplo, possam ser complementares e atuem juntos como substitutos brutos em relação ao trabalho. Por outro lado as informações disponíveis sobre renda da terra são muito parciais. Vanek (1963) analisa as dificuldades existentes quando se leva em conta a existência de um terceiro fator recursos naturais na teoria do comércio internacional. 
para mensurar as intensidades fatoriais. Somente em condições de concorrência perfeita e mobilidade perfeita de fatores as duas medidas levariam a obter o mesmo conteúdo de fatores e, portanto, seriam igualmente válidas. Por outro lado, a utilização da primeira medida exigiria construir séries de estoque de fatores. Entretanto, os dados disponíveis sobre investimento não se apresentam no nível de detalhe requerido, de tal forma que permitam uma base para fazer a mensuração do estoque de capital. Assim, não tendo esta informação, neste trabalho optou-se pela medida das participações dos fatores capital e trabalho na renda gerada em cada setor. Por outro lado para o cálculo do uso dos recursos naturais na produção dos bens, foi considerado o indicador do "coeficiente direto de recursos naturais". O coeficiente de requisitos diretos dos recursos naturais é obtido com base em dados da matriz insumo-produto, calculando para cada setor de atividade a participação dos produtos dos grupos: agropecuária, extrativa de minerais metálicos e combustíveis minerais. Essa variável é utilizada como proxy do uso direto de recursos naturais.

A mensuração das intensidades fatoriais no comércio Brasil-China foi realizada utilizando a matriz de insumo-produto, cuja estrutura desenvolvida por Leontief (1953), contém informações sobre renda gerada, discriminada entre salários, encargos sociais, excedente operacional e outras remunerações. Isto torna possível a mensuração da composição fatorial dos produtos com base na contribuição dos recursos produtivos na geração de renda em cada setor. Assim, partindo dos dados sobre remuneração do fator trabalho e valor adicionado em cada setor, pode-se obter como resíduo, a remuneração do fator capital. Alguns ajustes são necessários para se chegar à composição final do trabalho e do capital em cada produto ${ }^{10}$.

Apesar de teoricamente possível a existência de três fatores no modelo sobre comércio, há o problema relativo de como classificar os produtos segundo sua intensidade fatorial. A solução para este problema foi encontrada por Leamer (1987) ao desenvolver o método dos "Triângulos de Dotações", descrito a seguir. Para desenvolver este método foi utilizado um modelo de equilíbrio geral de "n" bens e três fatores de produção terra e recursos naturais (r), trabalho (l) e capital (k).

O modelo de Leamer foi originalmente utilizado para representar graficamente as dotações relativas dos três fatores para diferentes países. No entanto, a mesma análise pode ser utilizada a fim de representar as intensidades fatoriais por produto ${ }^{11}$. Londero e Teitel (1992) adaptaram o método do "Triângulo de Dotações" de Leamer para analisar a composição de insumos primários de alguns

10 As estimativas sofreram ajustes para se levar em conta a existência de distorções no preço dos fatores e o diferencial de salários rural-urbano na economia brasileira.

11 No modelo, o problema da análise gráfica em três dimensões é superado por Leamer (1987), pela intercepção do ortante positivo no espaço dos fatores em três dimensões, formando o "Triangulo de Dotações". 
produtos manufaturados exportados pela Argentina e Colômbia. A classificação e localização gráfica da intensidade fatorial dos produtos podem ser descritas com o auxílio da Figura 1 da seguinte maneira: produtos localizados nas regiões 1 e 2 $(\mathrm{r} / \mathrm{l}>\mathrm{le} \mathrm{k} / \mathrm{r}<1)$ são considerados intensivos em recursos naturais, produtos localizados nas regiões 3 e $4(\mathrm{r} / \mathrm{l}<1$ e $\mathrm{k} / \mathrm{l}<1)$ são intensivos em trabalho, e finalmente produtos localizados nas regiões 5 e $6(\mathrm{k} / \mathrm{l}>1 \mathrm{e} \mathrm{k} / \mathrm{r}>1)$ são considerados produtos intensivos em capital.

\section{Resultados Obtidos}

O conjunto de dados utilizados a fim de calcular o uso dos fatores de produção nos diferentes setores produtivos da economia brasileira foi obtido da Matriz de Insumo-Produto de 2005 elaborada pelo Instituto Brasileiro de Geografia e Estatística (IBGE). Por outro lado os fluxos comerciais do Brasil, segundo produtos e países de destino e origem foram obtidos do Ministério do Desenvolvimento, Indústria e Comércio (MDIC) e disponíveis através do Sistema Alice. As informações sobre o comércio estão disponíveis segundo classificação da Nomenclatura Comum do Mercosul (NCM). Assim, foi necessário realizar a compatibilização dos dados sobre o comércio exterior no período proposto no trabalho, a fim de tornálos compatíveis com a respectiva classificação da Matriz de Insumo-Produto do Brasil de 2005 elaborada pelo IBGE.

Os dados objetos deste trabalho referem-se ao período de 1989-2009. Assim inicialmente na subseção 4.1 é apresentada a classificação dos produtos segundo a sua intensidade fatorial relativa obtida, e na subseção 4.2 realiza-se a análise dos resultados obtidos e do comportamento das vantagens comparativas para o comércio Brasil-China.

\subsection{Classificação dos Setores Produtivos segundo a Intensidade Fatorial}

Com base nos dados disponíveis na Matriz de Insumo-Produto do Brasil e utilizando a metodologia desenvolvida por Leamer (1987) e adaptada por Londero e Teitel (1992), descrita na seção anterior, foi possível construir a Figura 1 relativa à classificação da estrutura fatorial dos diferentes setores que compõem a matriz de insumo-produto para a economia brasileira para o ano de 2005.

$\mathrm{Na}$ classificação da estrutura fatorial os setores que se localizam na região 1 e 2 da Figura 1, apresentam coeficientes $k / r<1$ e r/l $>1$ e são classificados como produtos intensivos em recursos naturais. Para o Brasil no ano de 2005, foram classificados como produtos intensivos em recursos naturais os setores de: Agropecuária e Silvicultura, Pecuária e Pesca, Minério de Ferro, Outros da Indústria Extrativa Mineral (Exceto Combustíveis), Alimentos e Bebidas, Produtos de Fumo, Celulose 
e Produtos de Papel, Petróleo e Gás, Álcool, Defensivos Agrícolas, Cimento, Outros Produtos Minerais Não Metálicos, Fabricação de Aço e Derivados.

Figura 1 - Classificação dos produtos segundo as intensidades fatoriais

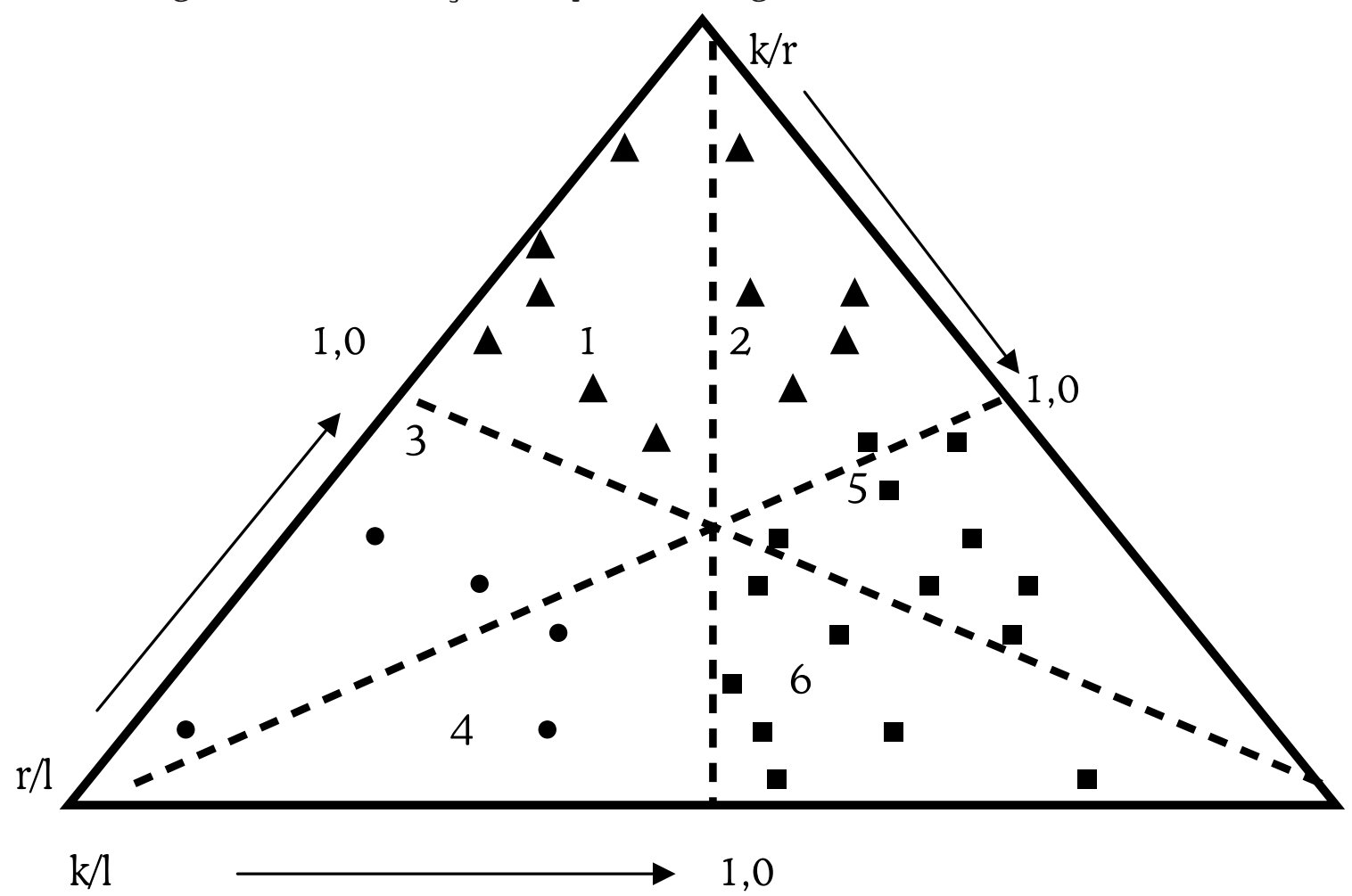

Fonte: Elaborada pelo autor a partir de dados da Matriz de Insumo-Produto do Brasil de 2005.

Nota: $\Delta$ Setores Intensivos em Recursos Naturais, regiões 1 e 2 do triângulo;

- Setores Intensivos em Trabalho, regiões 3 e 4 do triângulo;

- Setores Intensivos em Capital, regiões 5 e 6 do triângulo.

Por outro lado, os setores que possuem os coeficientes $r / l<1$ e $k / 1<1$, localizados nas regiões 3 e 4 são classificados como intensivos em trabalho. Para o Brasil em 2005 foram classificados como setores intensivos em trabalho os produtos dos setores de: Têxteis, Artigos de Vestuário e Acessórios, Artefatos de Couro e Calçados, Produtos de Madeira-Exclusive Móveis, Móveis e Produtos das Indústrias Diversas.

Finalmente os produtos intensivos em capital, caracterizados por terem maior valor agregado, têm o maior número de setores das três categorias analisadas. Nesta categoria, são classificados como tais os produtos dos setores que possuem coeficientes $\mathrm{k} / \mathrm{l}>1 \mathrm{e} \mathrm{k/r}>1$ e pertencem às regiões 5 e 6 na classificação do triângulo acima. Os produtos que pertencem a esta categoria são os seguintes setores: Refino de Petróleo e Coque, Produtos Químicos, Fabricação de Resina e Elastômeros, Produtos Farmacêuticos, Perfumaria, Higiene e Limpeza, Tintas, Vernizes e Esmaltes, Produtos Químicos Diversos, Artigos de Borracha e Plástico, 
Metalurgia de Metais não Ferrosos, Produtos de Metal (Exclusive Máquinas), Jornais Revistas e Discos, Máquinas e Equipamentos (Inclusive, Eletrodomésticos), Máquinas para Escritório, Máquinas, Aparelhos e Materiais Elétricos, Material Eletrônico e Equipamento Comum, Aparelhos, Instrumentos Médicos Hospitalares, Automóveis, Camionetes e Utilitários, Caminhões e Ônibus, Peças e Acessórios para Veículos, Outros Equipamentos de Transporte (ver Figura 1).

\subsection{Intensidades Fatoriais no Comércio Brasil-China}

A classificação dos setores produtivos segundo a intensidade fatorial da subseção anterior foi utilizada para calcular as intensidades fatoriais no comércio bilateral Brasil-China. Os principais resultados obtidos para o Brasil nas relações comerciais com a China estão apresentados nos Gráficos 3 e 4, a seguir, os resultados são relativos ao período de 1989 a 2009. O Gráfico 3, mostra a participação das exportações brasileiras segundo as intensidades fatoriais relativas no comércio com a China. Os resultados mostram claramente que no comércio entre os dois países existe um predomínio de exportações brasileiras intensivas em recursos naturais ao longo de todo o período analisado, seguido, porém em patamar muito inferior, de exportações brasileiras de bens intensivos em trabalho.

Analisando o comportamento histórico do Gráfico 3, observa-se em destaque três momentos distintos ao longo do período analisado. O primeiro período mostra um aumento do distanciamento na participação relativa das exportações brasileiras, entre bens intensivos em capital e bens intensivos em recursos naturais. Esta tendência é refletida pelo aumento de 1989 a 1991, na participação relativa dos bens intensivos em recursos naturais e redução dos bens intensivos em capital. O segundo movimento ocorre em 1992, ao convergir a participação das exportações intensivas em estes dois fatores, quando os produtos intensivos em capital aumentam sua participação relativa para $34,1 \%$ e os produtos intensivos em recursos naturais reduzem sua participação para $62,6 \%$ do total exportado pelo Brasil para a China. O terceiro movimento, que se inicia a partir de 1993 e segue até o fim do período analisado, onde apesar de pequenas oscilações os produtos do grupo de bens intensivos em recursos naturais aumentaram a sua participação, reduzindo a participação de produtos intensivos em capital no total de bens exportados pela economia brasileira para a economia chinesa.

Quanto aos bens intensivos em recursos naturais observa-se também no Gráfico 3, que eles apresentam uma representatividade média acima de 70,0\% ao longo do período, e com aumento desta participação relativa para o fim do período analisado. Assim nota-se que em 1989, as exportações brasileiras de bens intensivos em recursos naturais representavam $77,8 \%$ do total exportado. No entanto, a crescente inserção da China no comércio internacional fez com que este país ocupasse espaço significativo no comércio exterior brasileiro. Este movimento fez 
com que as exportações de bens intensivos em recursos naturais aumentassem sua participação relativa, atingindo o patamar de 87,8\% em 1998. Na última década, o crescimento da demanda mundial, e da chinesa em particular, por "commodities" foi outro fator que induziu o aumento da representatividade do setor de bens intensivos em recursos naturais brasileiros para o mundo e em particular para China, chegando a atingir uma participação de 91,2\% em 2008 e 90,7\% em 2009 ${ }^{12}$, do total exportado pela economia brasileira para a China.

12 Ressalte-se, porém, que o comércio internacional de 2009, foi afetado pela crise financeira internacional de 2008, reforçando a tendência pelo Brasil na exportação de bens primários. 


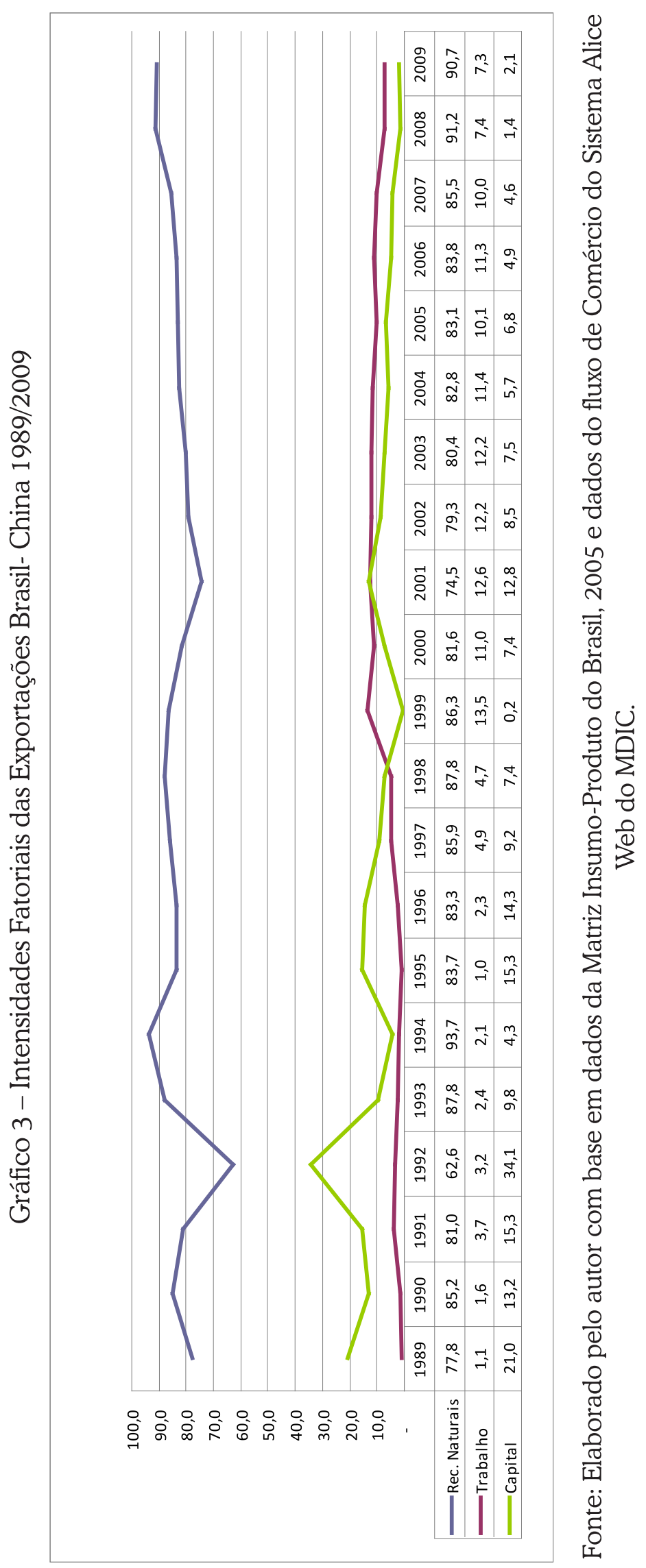


A evolução desse padrão de comércio bilateral Brasil-China tem recentemente suscitado debate sobre suas implicações para a economia brasileira. Alguns autores argumentam que a "primarização" da pauta exportadora brasileira é um subproduto da demanda chinesa. Argumenta-se também que esse comportamento pode gerar efeitos significativos sobre a economia do Brasil no futuro e aumentar a participação dos setores tradicionais na estrutura produtiva do país ${ }^{13}$.

Com relação aos bens intensivos em trabalho, observa-se no Gráfico 3, que a participação desses bens nas exportações brasileiras teve aumento significativo de 1,1\% em 1989 para 13,5\% em 1999, reduzindo-se porém para 7,3\% em 2009, mas ainda em um patamar superior ao verificado no inicio do período. Ressaltase, que por serem produtos sensíveis à volatilidade cambial, os bens intensivos em trabalho foram muito afetados pelas variações cambiais sofridas pela economia brasileira ao longo dos anos 90. Estes bens tiveram de 1994 a 1998 (período de estabilidade monetária e valorização da moeda) participação relativa média de apenas 2,6\% e em anos posteriores de 2000 até 2005, ou seja, período pós-desvalorização cambial, a participação relativa média aumentou significativamente para $11,85 \%$ das exportações. No entanto, nos últimos quatro anos da série, estes bens mostraram tendência à queda de participação nas exportações atingindo em 2008, a participação de $7,4 \%$ do total exportado pelo Brasil para a China, porém em um patamar muito superior ao registrado no inicio do período.

Quanto aos bens intensivos em trabalho, cabe observar também que após a desvalorização da moeda brasileira em 1999, os produtos intensivos em trabalho com $13,5 \%$ de participação relativa passaram a ter uma representatividade maior que os bens intensivos em capital no período. Ressalte-se, também que no ano de 1999 com apenas 0,2\% de participação relativa, as exportações de bens intensivos em capital atingiram sua mínima representatividade em todo o período analisado.

Ainda, com relação à importância relativa dos bens intensivos em trabalho, estes se fazem sentir mais presentes quando no ano de 1999 sua representatividade supera a dos bens intensivos em capital e se mantêm com uma média de 10,4\%, em comparação a média de $5,1 \%$ dos bens intensivos em capital até o final do período. Como já foi dito esta situação era inversa até então, quando do ano de 1989 até o ano de 1998 os bens intensivos em trabalho eram responsáveis, em média, por apenas $2,6 \%$ das exportações e os bens intensivos em capital por $14,4 \%$ dos produtos exportados pelo Brasil para a economia chinesa.

13 Sobre a "primarização" das exportações brasileiras ver, por exemplo, De Negri e Alvarenga (2011). Fishlow e Bacha (2010) discutem a ascensão da China, Índia e outros países asiáticos com "fome de commodities", e a crescente importância dos mercados financeiros internacionais na determinação dos preços e influenciando o mercado dessas commodities no século XXI. Os autores revisam a literatura sobre a relação entre exploração de recursos naturais e o declínio, ou não, do setor industrial em alguns países latino-americanos. 
Analisando agora o comportamento dos bens intensivos em capital, os resultados mostram que ao longo do período de 1989 a 2000 houve uma redução significativa na participação relativa destes produtos nas exportações brasileiras para China. A análise da evolução do uso dos fatores de produção mostra que as exportações de produtos intensivos em capital representavam em 1989 cerca de 21,0\%, das exportações brasileiras para a China. Observa-se também no Gráfico 3, que seguidamente houve aumento na importância relativa dos produtos intensivos em capital até o ano 1992 quando atingem o máximo histórico de 34,1\% de representatividade nas exportações brasileiras. Porém, após este período, os produtos intensivos em capital reduzem significativamente sua importância relativa a níveis inferiores de 1989, atingindo o valor representativo de apenas 1,4\% em 2008 e 2,1\% em 2009.

No Gráfico 4 apresenta-se a intensidade fatorial das importações brasileiras da China, resultados relativos ao período de 1989 a 2009. Diferente das exportações os resultados do Gráfico 4 mostram uma tendência de predomínio de produtos importados intensivos em capital ao longo do período analisado, que tem como contrapartida a participação das importações de produtos intensivos em recursos naturais e seguido, em patamar bem inferior, as importações de bens intensivos em trabalho. No entanto, esta situação não foi definitiva ao longo do período, pois em 1989 os bens intensivos em recursos naturais representavam 80,3\% das importações brasileiras da China, superando em muito as importações dos bens intensivos em capital, que representavam $15,6 \%$ naquele ano, ficando os produtos intensivos em trabalho com apenas $4,1 \%$ do total de bens importados pela economia brasileira da China neste ano.

Analisando agora o comportamento das importações de bens intensivos em trabalho observa-se que as mesmas tiveram um crescimento de participação de 4,1 \% em 1989 para 25,6 \% em 1995. Esse crescimento pode ser explicado pela estabilidade cambial e pela abertura comercial, que implicou na redução das tarifas e restrições a importações nesse período. Entretanto, após esse ano a participação das importações de bens intensivos em trabalho começou a cair, principalmente após a desvalorização do Real em 1999, situando-se em um patamar de participação média de 10,4\% durante o período 2000 a 2009.

Quanto à participação dos bens intensivos em capital, que também foram afetados pela intensificação da abertura comercial e pela modernização da economia brasileira no inicio dos anos 90 , suas participações relativas se alteraram significativamente em relação às importações da China. Assim, já em 1992 logo após a intensificação da abertura comercial e do comércio mais livre no Brasil, a participação dos bens intensivos em capital passou a representar 50,7\% das importações totais, superando os bens intensivos em recursos naturais que atingiram, neste ano, uma participação relativa de $40,4 \%$, ou seja, a metade da participação verificada em 1989. 


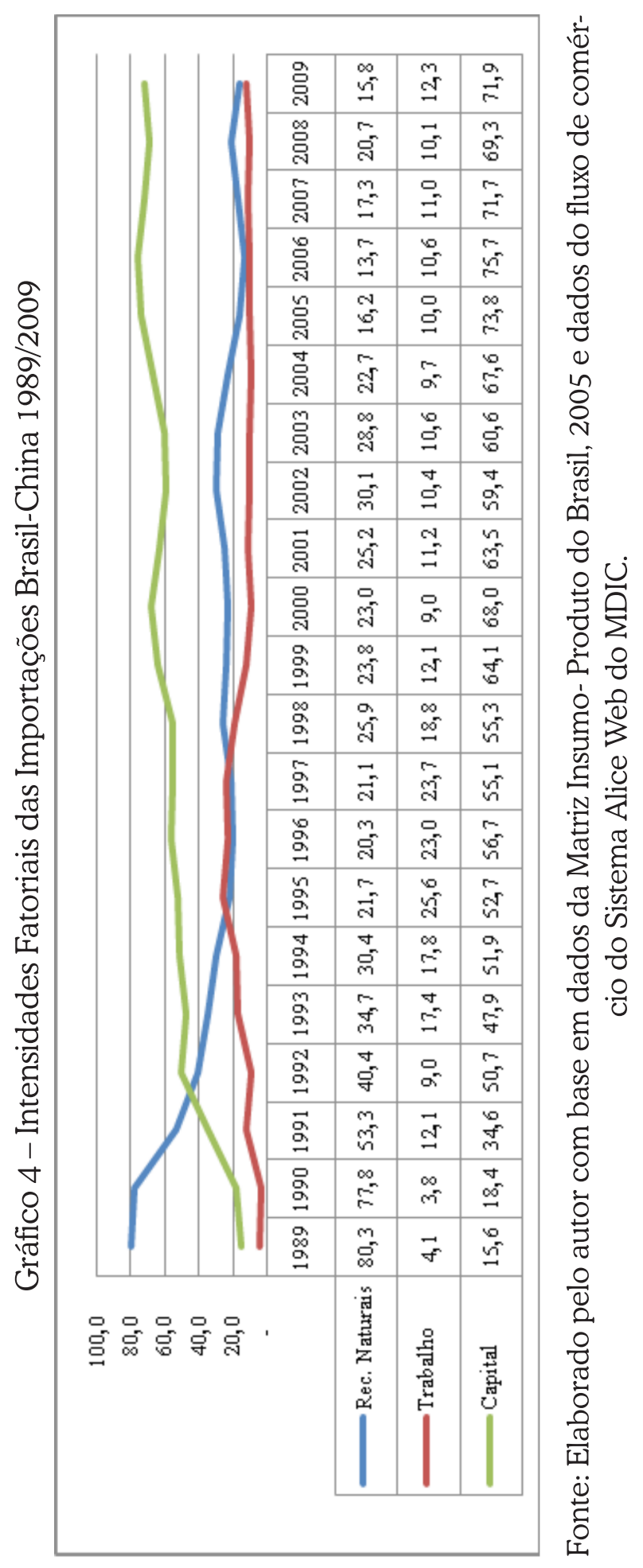

FEISTEL, P. R.; HIDALGO, A. B. O intercâmbio comercial Brasil-China: a questão... 
Embalada pela maior inserção da economia chinesa no mercado internacional, em particular no Brasil, essa tendência de especialização no comércio se intensificou ao longo do período com o aumento significativo da participação de importações brasileiras de bens intensivos em capital e recuo dos bens intensivos em recursos naturais. Este comportamento de especialização no comércio atinge seu ápice no ano de 2006, quando as importações brasileiras de bens intensivos em capital passaram a representar $75,7 \%$ do total importado pelo Brasil da China. Por outro lado, nesse ano as importações de bens intensivos em recursos naturais representavam apenas 13,7\% do total importado da China, (ver o Gráfico 4).

Em resumo, os resultados obtidos sobre a evolução das intensidades fatoriais no comércio bilateral Brasil-China nos últimos vinte anos parecem mostrar uma tendência de especialização comercial segundo os princípios das vantagens comparativas, caso se admita a economia brasileira como sendo relativamente mais bem dotada de recursos naturais quando comparada com a economia chinesa, $\mathrm{e}$ a economia chinesa relativamente mais bem dotada de capital e trabalho do que a economia brasileira.

\section{Considerações Finais}

O estudo das relações comercias Brasil-China tem despertado cada vez maior interesse na literatura. Neste trabalho foram analisados diversos aspectos do padrão de comercio entre os dois países. $\mathrm{O}$ assunto é relevante tendo em vista a crescente importância da economia chinesa no cenário internacional e o crescimento do fluxo comercial verificado entre os dois países nas duas últimas décadas. No ano de 2009 a China se mostra como o mais importante parceiro comercial do Brasil, posição esta antes ocupada pelos Estados Unidos.

Foi verificado que ao longo das duas últimas décadas os grupos de produtos primários (Alimentos, Bebidas e Minerais) tiveram altas taxas de crescimento nas exportações brasileiras para a China, fazendo com que a participação desses grupos de primários passasse a representar quase $80 \%$ do total exportado no ano de 2009. Os produtos manufaturados por sua vez, tiveram uma queda significativa na participação relativa nas exportações ao longo do período analisado.

Verifica-se que diferente das exportações, no período as importações brasileiras apresentam uma redução significativa na participação relativa dos grupos de produtos primários, e um correspondente aumento na participação relativa dos manufaturados, principalmente daqueles mais intensivos em capital.

Os baixos índices de comércio intraindústria observados entre os dois países e a baixa (alta) intensidade tecnológica das exportações (importações) brasileiras, parecem mostrar uma tendência de especialização do comércio exterior brasileiro com a China segundo os princípios das vantagens comparativas estáticas, princi- 
palmente durante o período recente. Parece existir consenso de que a economia brasileira é relativamente mais bem dotada de recursos naturais (terra e minerais abundantes), e menos bem dotada de trabalho e capital em relação à China. Os resultados obtidos neste trabalho sobre as intensidades fatoriais no comércio entre os dois países mostram que de fato há uma tendência de longo prazo de aumento de participação dos produtos intensivos em recursos naturais e queda de participação dos produtos intensivos em capital e trabalho na pauta de exportações brasileiras. Esse padrão de comércio com a China parece estar contribuindo recentemente para acelerar o processo de "primarização" das exportações do Brasil, e que poderá ter consequências de médio e longo prazo sobre a estrutura produtiva da economia brasileira.

Por outro lado no que se referem às importações, estas mostram uma inequívoca tendência de crescente participação dos produtos intensivos em capital e uma queda de participação de produtos intensivos em recursos naturais.

As evidências observadas no comércio Brasil-China parecem ser mais um exemplo da tendência natural de aproveitamento de vantagens naturais de cada país diante de um comércio internacional cada vez mais livre. O fenômeno de especialização parece ser de longo prazo e fruto de aproveitamento de vantagens comparativas no comércio internacional.

O comércio internacional oferece oportunidades de crescimento para uma economia, aproveitar essas oportunidades, porém, exige de o país seguir uma política comercial em sintonia com as mudanças que se verificam no padrão de vantagem comparativa.

Os desafios que o comércio Brasil-China parece criar para o futuro do comércio brasileiro parecem estar relacionados com a formulação de uma política científica, tecnológica e comercial que permita a qualificação e a incorporação de maior valor agregado nos produtos que o país exporta para essa nação. A política comercial precisa ser orientada para a tecnologia e a inovação a fim de tornar os setores com vocação mais modernos e competitivos. Porém, cabe lembrar que o sucesso no comércio com base nas vantagens comparativas depende também do andamento das negociações no âmbito da Organização Mundial do Comércio. As eliminações das restrições tarifárias e não tarifárias, incluindo as tarifas moduladas, são fundamentais para o sucesso da estratégia com base nas vantagens comparativas.

Outra questão de natureza geoeconômica nas relações comerciais com China, não discutida neste trabalho, porém não menos importante, refere-se ao deslocamento de parceiros comerciais importantes do Brasil, na América Latina e África, por exemplo, para a China.

Igual a todo trabalho de natureza empírica este também apresenta suas limitações. Talvez a mais importante refere-se aos dados que foram utilizados nos cálculos das intensidades de fatores. Idealmente o cálculo das intensidades fatoriais 
deveria ser realizado com base no estoque físico dos insumos capital, trabalho e recursos naturais necessários para produzir os bens. Tendo em vista as dificuldades para obter essas informações foi necessário fazer uso da medida das participações dos fatores na renda gerada em cada setor, este procedimento, porém depende de algumas hipóteses que foram feitas. Outra limitação também importante refere-se ao fato de ter sido utilizada apenas uma matriz de insumo-produto de 2005 para realizar os cálculos, o período de vinte anos que foi considerado é muito longo e certamente aconteceram mudanças tecnológicas importantes e que não foram consideradas. Melhores resultados certamente poderiam ser obtidos levando em conta esses elementos.

\section{Referências}

CEPAL. División de Comercio Internacional e Integración. 2010. Disponível em: <http:/www. eclac.cl/comercio/serieCP/eclactrade/serie_spanish_110.htm > . Acesso em: 20 ago. 2010.

CEPAL. La República Popular China y América Latina y el Caribe: hacia una relación estratégica. 2010. Disponível em:<http://eclac.org.>. Acesso em: 20 ago. 2010.

CUNHA, A. M. et al. Breves considerações sobre os impactos potenciais da ascensão da china na economia brasileira. In: SEMINÁRIO SOBRE PESQUISAS EM RELAÇÕES ECONÔMICAS INTERNACIONAIS, 2, 2010, Brasília. Anais... Brasília: FUNAG, 2011.

DE NEGRI, F.; ALVARENGA, G. V. A primarização da pauta de exportações no Brasil: ainda um dilema. Radar: tecnologia, produção e comércio exterior, Brasília, n. 13, p. 7-14, abr. 2011.

DEVLIN, R.; ESTEVADEORDAL, A.; RODRÍGUEZ, A. (Ed.). The emergence of China-opportunities and challenges for Latin America and the Caribbean. Washington, D. C.: BID, 2006.

FEISTEL, P. R. A Natureza do Comércio das Regiões Brasileiras no MERCOSUL. 2006. Tese (Doutorado em Economia) - Departamento de Economia, Universidade Federal de Pernambuco, Recife, 2006.

FEISTEL, P. R.; HIDALGO, A. B. O comércio das regiões brasileiras nordeste sudeste e sul no MERCOSUL: uma abordagem das vantagens comparativas. In: ENCONTRO NACIONAL DE ECONOMIA DA ANPEC, 37, 2009, Foz do Iguaçu. Anais... Foz do Iguaçu: ANPEC, 2009.

FISHLOW, A.; BACHA, E. Recent commodity price boom and Latin American growth: more than new bottles for an old wine? In: OCAMPO, J. A.; ROS, J. (Ed.). Handbook of Latin American economics. Oxford: Oxford University Press, 2010.

GRUBEL, H. P.; LLOYD, P. J. Intra-industry trade: the theory and measurement of international trade in differentiated products. London: Mc Millan, 1975.

HIDALGO, A. Intensidades fatoriais na economia brasileira: novo teste empírico do Teorema de Heckscher-Ohlin. Revista Brasileira de Economia, Rio de Janeiro, v. 39, n 1, p. 27-55, jan./ mar. 1985.

. Industrialização e a mudança no conteúdo de insumos das exportações brasileiras. Revista Econômica do Nordeste, Fortaleza, v. 27, n· 3, p. 433-448, jul./set. 1996. 
HIRATUKA, C.; SARTI, F. Ameaça das exportações chinesas nos principais mercados de exportações de manufaturados do Brasil. In: ENCONTRO NACIONAL DE ECONOMIA POLÍTICA, 14, 2009, São Paulo. Anais... São Paulo: SEP, 2009.

INSTITUTO BRASILEIRO DE GEOGRAFIA E ESTATÍSTICA. Coordenação de Contas Nacionais. Matriz insumo-produto: Brasil 2000/2005. Rio de Janeiro: IBGE, 2008.

JORGE, M. F.; KUME, H. A competitividade do Brasil e da China no mercado norte-americano no período 2000-2008. In: ENCONTRO NACIONAL DE ECONOMIA DA ANPEC, 37, 2009, Foz do Iguaçu. Anais... Foz do Iguaçu: ANPEC, 2009.

KEMP, M. C. The pure theory of international trade and investment. New Jersey: Prentice-Hal, 1969. Cap. 3.

LEAMER, E. Paths of development in the three-factor, n-good general equilibrium mode. The Journal of Political Economy, Chicago, v. 95, n. 5, p. 961-999, Oct. 1987.

LÉLIS, M. T. C.; CUNHA, A. M.; LIMA, M. G. O desempenho das exportações do Brasil e da china na América Latina entre 1994 e 2009. In: ENCONTRO NACIONAL DE ECONOMIA DA ANPEC, 38, Salvador, 2010. Anais... Salvador: ANPEC, 2010.

LEONTIEF, W. Domestic production and foreign trade: the American capital position re-examined. Proceedings of the American Philosophical Society, Philadelphia, v. 97, n. 4, p. 332-349, Sep. 1953.

LONDERO, E.; TEITEL, S. Industrialización, exportaciones de manufacturados y contenido de insumos primários. In: ENCONTRO LATINO AMERICANO DA SOCIEDADE ECONOMÉTRICA, 11.,1992, Cidade do México. Anais... Cidade do México: [s.n.], 1992.

MACHADO, J. B.; FERRAZ, G. Comércio externo da China: efeitos sobre as exportações brasileiras. Brasília: IPEA, 2006. (Textos para Discussão, n. 1182).

SAMUELSON, P. A. Prices of Factors and Goods in General Equilibrium. Review of Economic Studies, Bristol, v. 21, n. 1, p. 1-20, 1953, 1954.

SILVA, A. D. B. Um estudo das relações comerciais entre Brasil e China e da concorrência chinesa em terceiros mercados. 2011. Dissertação (Mestrado em Economia) - Departamento de Economia, Universidade Federal de Pernambuco, Recife, 2011.

THORSTENSEN, V. et al. O Brasil frente a um mundo dividido em blocos. São Paulo: Nobel, 1994.

VANEK, J. The natural resource content of United States foreign trade 1870-1955. Cambridge: MIT Press, 1963.

VASCONCELOS, C. R. F. O comércio Brasil- MERCOSUL na década de 90: uma análise pelas óticas da intensidade fatorial, comércio intra-indústria e criação e desvio de comércio. 2000. Tese (Doutorado em Economia) - Departamento de Economia, Universidade Federal de Pernambuco, Recife, 2000.

Recebido em: 27/09/2010.

Aceito em: 18/06/2011. 